\title{
Neoplasia detection in Macoma balthica from the Gulf of Gdansk: comparison of flow cytometry, histology and chromosome analysis
}

\author{
K. Smolarz ${ }^{1}$, T. Renault ${ }^{2, *}$, P. Soletchnik ${ }^{3}$, M. Wolowicz ${ }^{1}$ \\ ${ }^{1}$ Laboratory of Estuarine Ecology, Institute of Oceanography, University of Gdansk, Al. Pilsudskiego 46, \\ 81-378 Gdynia, Poland \\ ${ }^{2}$ Laboratoire de Génétique et Pathologique, and ${ }^{3}$ Laboratoire Conchylicole de Poitou Charentes, IFREMER, \\ 17390 La Tremblade, France
}

\begin{abstract}
A flow cytometry protocol was applied for the detection of neoplasia in Macoma balthica L. from the Gulf of Gdansk (Baltic Sea, Poland). A simple method, based on an osmotic shock, was used to permeabilise gill cells. The cytometric pattern of normal clams consisted of 2 peaks, a major peak B and a smaller peak C. The cytometric pattern of affected clams consisted of 2 peaks named B' and $\mathrm{C}^{\prime}$. Two parameters were used to define the stages of abnormalities in $M$. balthica clams based on the percentage of cells in peaks $B, C, B^{\prime}$ and $C^{\prime}$ and on the ratio between the fluorescence value of peaks $B, C, B^{\prime}$ and $C^{\prime}$ in all individuals. Three stages of neoplasia were clearly distinguished by flow cytometry considering peak $C^{\prime}$. Stage 1 was characterised by a major population of cells in peak $\mathrm{B}^{\prime}$ and more than $10 \%$ of cells in the $\mathrm{C}^{\prime}$ peak. Stage 2 consisted of a lower percentage of cells in peak $\mathrm{B}^{\prime}$ and more than $25 \%$ of cells in peak $\mathrm{C}^{\prime}$. Stage 3 of the neoplasia was characterised by a further reduction in peak $\mathrm{B}^{\prime}$ and more than $40 \%$ of cells in peak $\mathrm{C}^{\prime}$. Flow cytometry allowed for objective detection of neoplasia and provided a rapid method for measuring the DNA content of thousands of cells per individual. The accuracy of flow cytometry was assessed by comparing with standard histological techniques, used here as a reference technique for the detection of neoplasia, and with chromosome analysis. All individuals were analysed in parallel using the 3 techniques. The proportion of normal and affected individuals diagnosed using flow cytometry was comparable to the proportion determined by histology and chromosome analysis.
\end{abstract}

KEY WORDS: Flow cytometry $\cdot$ Histology $\cdot$ Cytogenetics $\cdot$ Neoplasia $\cdot$ Macoma balthica $\cdot$ Baltic Sea

\section{INTRODUCTION}

Most neoplasia reported from bivalves have been described as a disturbed cell growth pattern characterised primarily by excessive cell proliferation. Three main cytological characteristics are associated with neoplastic cells: nuclear polymorphism, nuclear hyperchromasia and cellular polymorphism. Other features include the presence of more than 1 nucleoli in the nucleus, a high frequency of mitotic figures and a high nucleus to cytoplasm ratio (Mix 1983, Krishnakumar et al. 1999). In molluscs, most identified neoplasms have been described as sarcomas of haematopoietic origin (Bower et al. 1994, Rodriguez et al. 1997) because of cellular hypertrophy and presence of a large lobate nucleus. To date, disseminated neoplasia have been reported in various bivalve species (Elston et al. 1992, Villalba et al. 2001).

Environmental carcinogens such as hydrocarbons (Yevich \& Barszcz 1977, Naes et al. 1995), herbicides (van Beneden et al. 1993), biotoxins (Landsberg 1996, Roy et al. 1998) and infectious agents (Farley et al. 1972, Ford et al. 1997) have been suggested as the main risk factors for disseminated neoplasia. Research on mollus- 
can neoplasia has been motivated by the question as to whether bivalves can be used as bioindicators in environmental monitoring (Roy et al. 1998, Brousseau et al. 2000, Fournier et al. 2001, Sauve et al. 2002).

High prevalence of neoplasia can be found in Macoma balthica L. sampled from industrialised waterways around the Gulf of Gdansk in Poland (Thiriot-Quiévreux \& Wolowicz 1996, 2001). Clams at these sites are known to be exposed to a range of chemical carcinogens and pollutants (Wolowicz 1994, Szefer et al. 1996, Sokolowski et al. 1999, Hummel et al. 2000). Neoplasia in $M$. balthica have also been reported from the Chesapeake Bay (Christensen et al. 1974) and Finnish coast (Pekkarinen 1993).

This report describes a flow cytometry protocol for the detection of gill neoplasia in Macoma balthica from the Gulf of Gdansk (Baltic Sea, Poland). Flow cytometry has already been used to investigate disseminated neoplasia in molluscs (Elston et al. 1990, Moore et al. 1991, Reno et al. 1994). In the present study, a new method of cell lysis based on a hyposmotic shock has been developed and a combined comparison of the flow cytometry method, histology and chromosome analysis is reported for the time.

\section{MATERIALS AND METHODS}

Clams. Clams Macoma balthica $(16 \pm 4 \mathrm{~mm}$ mean valve length) were collected in 2002 by dredging in the Gulf of Gdansk. Clams were maintained for 2 to $5 \mathrm{wk}$ in the IFREMER laboratory (La Tremblade, France) in tanks each containing $20 \mathrm{dm}^{3}$ seawater $\left(13 \pm 2{ }^{\circ} \mathrm{C}\right)$. They were fed daily with Isochrysis sp. algae. Prior to analysis, clams were incubated for $8 \mathrm{~h}$ in colchicine $(0.005 \%$ in sea water $)$. Colchicine is used as an antimitotic agent for chromosome analysis. Samples from all individuals were analysed by flow cytometry, histology and chromosomal analysis.

Histology. Thirty clams were removed from their shells, and gill tissues were collected for flow cytometry and chromosome analysis. Each individual was placed in Davidson's fixative for $48 \mathrm{~h}$. Samples were dehydrated through an ascending ethanol series, cleared in xylene and embedded in paraffin. Sections $(2 \mu \mathrm{m})$ were stained with hematoxylin and eosin (H\&E) and examined to determine the presence of neoplastic cells. Identified cases of neoplasia were classified from I to IV, according to Christensen et al. (1974) and Pekkarinen (1993).

Flow cytometry. Gill tissues from each individual were placed in $0.5 \mathrm{ml}$ sterile distilled water. Tissues were ground in an Eppendorf tube using a disposable tissue homogeniser, and the cell suspension was filtered through a $60 \mu \mathrm{m}$ sterile mesh. After filtration, each sample was adjusted to $0.5 \mathrm{ml}$ with sterile distilled water and left for one $\mathrm{h}$ on ice to allow cell permeabilisation. Cell suspensions were subsequently used for analysis by flow cytometry within $2 \mathrm{~h}$ of preparation. Cell DNA content was assessed by staining DNA with propidium iodide (PI, Interchim) (final concentration $50 \mathrm{ng} \mathrm{ml}^{-1}, 30 \mathrm{~min}$ in the dark, $20^{\circ} \mathrm{C}$ ). Gill cells were analysed with an EPICS XL4 flow cytometer (Beckman Coulter). PI red fluorescence excited at $488 \mathrm{~nm}$ wavelength was collected through a $600 \mathrm{~nm}$ band pass filter and the data were registered on a logarithmic scale. For each gill sample, 3000 events were counted. Results were recovered as histograms presenting the cell fluorescence ( $x$-axis) and number of cells ( $y$-axis).

Chromosome analysis. Gill tissues from each individual were placed in sodium citrate $(0.9 \%)$ in distilled water for $45 \mathrm{~min}$, then fixed with 4 baths $(2 \times 20 \mathrm{~min}$ and $2 \times 10 \mathrm{~min}$ ) of absolute ethanol:acetic acid (3:1). Slides were prepared for each individual using an airdrying technique (Thiriot-Quiévreux \& Ayraud 1982) and stained with Giemsa (Sigma, $4 \%$ ) in distilled water (pH 6.8) for $8 \mathrm{~min}$. Mitoses were observed using light microscopy.

Statistical analysis. Statistical analysis of flow cytometry peaks ( $B, B^{\prime}, C$ and $C^{\prime}$ ) including test of normality, was performed using analysis of variance and a multiple comparison test according to the least significant difference (LSD) method (Snedecor \& Cochran 1957), using Statgraphics version 3.1 software. Cytometric profile peaks, together with $\left(\mathrm{B} / \mathrm{B}+\mathrm{C}\right.$ and $\mathrm{B}^{\prime} / \mathrm{B}^{\prime}+$ $\left.C^{\prime}\right)$ variables, were converted into angular arc sine $\sqrt{ }$ (\% of variable) before analysis. The 3 stages of neoplasia defined by flow cytometry were compared using ANOVA.

\section{RESULTS}

\section{Histology}

Thirty individual Macoma balthica, 15 of which were diagnosed by histology as normal (Fig. 1) and 15 of which displayed neoplastic changes (Fig. 2a,b) were selected in the present study. Affected cells were large, actively proliferative with pleomorphic nuclei. In stage I, abnormal cells were first found in gill epithelia. In stage II abnormal cells invaded gill connective tissues (Fig. 2a). In stage III, gills were severely affected and neoplastic cells diffused into other organs, while at stage IV, neoplasia was characterised by a partially damaged gill tissue, and the presence of neoplastic cells in all other organs (Fig. 2b). Five individuals were classified in stage I and II, 6 in stage III and 4 in stage IV (see Table 3). 


\section{Flow cytometry}

Preliminary experiments indicated that the use of fixed material (in ethanol:acetic acid), cell permeabilisation by water at different salinities or permeabilisation by buffer (containing $1 \%$ of Triton-X 100) prior to flow cytometric analysis of gill, resulted in poor separation of fluorescent peaks and high percentages of non-labelled events (Fig. 3a). The best definition of peaks occurred following permeabilisation by osmotic shock (Fig. 3b).

The cytometric profile of Macoma balthica, defined as normal using histological examination, consisted of a major peak (B) and a second smaller peak (C) (Fig. 4a). The mean value of fluorescence for peak $C$ was approximately double that of the fluorescence value of peak B (Table 1). Normal $M$. balthica were also characterised by a high number of cells in peak $B$ (Table 1). The percentage of cells in this peak ranged from 82.6 to $90.3 \%(85.9 \pm 2.2, \mathrm{~N}=15)$. The percentage of cells observed in the second peak (C) ranged from 5.0 to $7.5 \%(6.2 \pm 0.9, \mathrm{~N}=15)$. In normal clams, the relationship between mean fluorescence values of the first and the second peak was linear and the proportion between them was $\mathrm{C}$ peak $=2.04 \mathrm{~B}$ peak $+1(\mathrm{~N}=15$, range 1.7 to 2.2 with a mean value of $2.04, \mathrm{SD}=0.1$ ).

In clams diagnosed as neoplastic by histology (Table 2), 2 major peaks ( $\mathrm{B}^{\prime}$ and $\mathrm{C}^{\prime}$ ) were observed. In 5 individuals (stage 1), peaks consisted of a major B' peak $(72.3 \pm 5.8 \%)$, with smaller populations of cells in peak $C^{\prime}(15.5 \pm 4.1 \%)$ (Fig. 4 b). Neoplasia in 6 clams (stage 2) was characterised by a lower percentage of cells in peak B' $(61.3 \% \pm 3.1)$ and a higher percentage of cells in peak $C^{\prime}(29.2 \% \pm 1.7)$ (Fig. 4c). In 4 affected individuals (stage 3 ), the percentage of cells in each

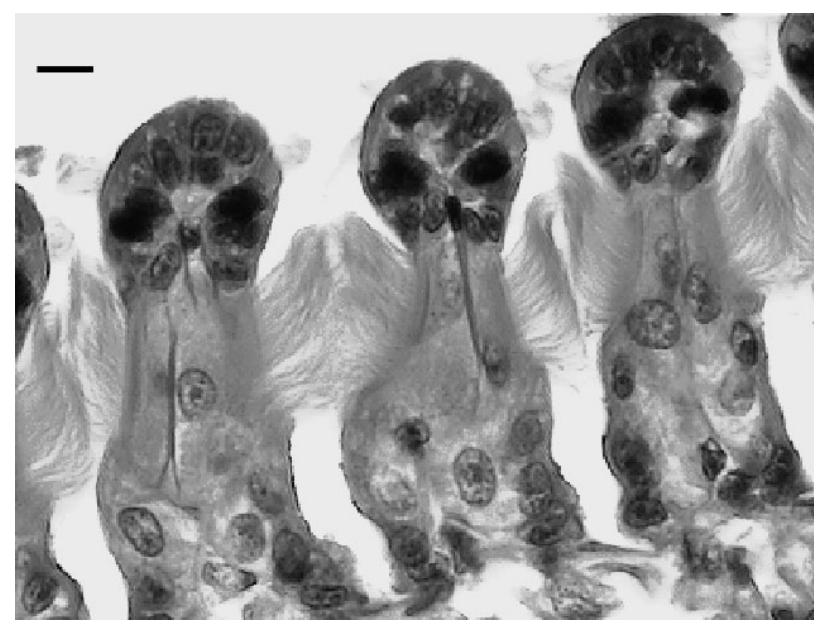

Fig. 1. Macoma balthica. Histological section of gill in a normal $M$. balthica (clam no. 3). Scale bar $=10 \mu \mathrm{m}$, hematoxylin and eosin (H\&E) staining
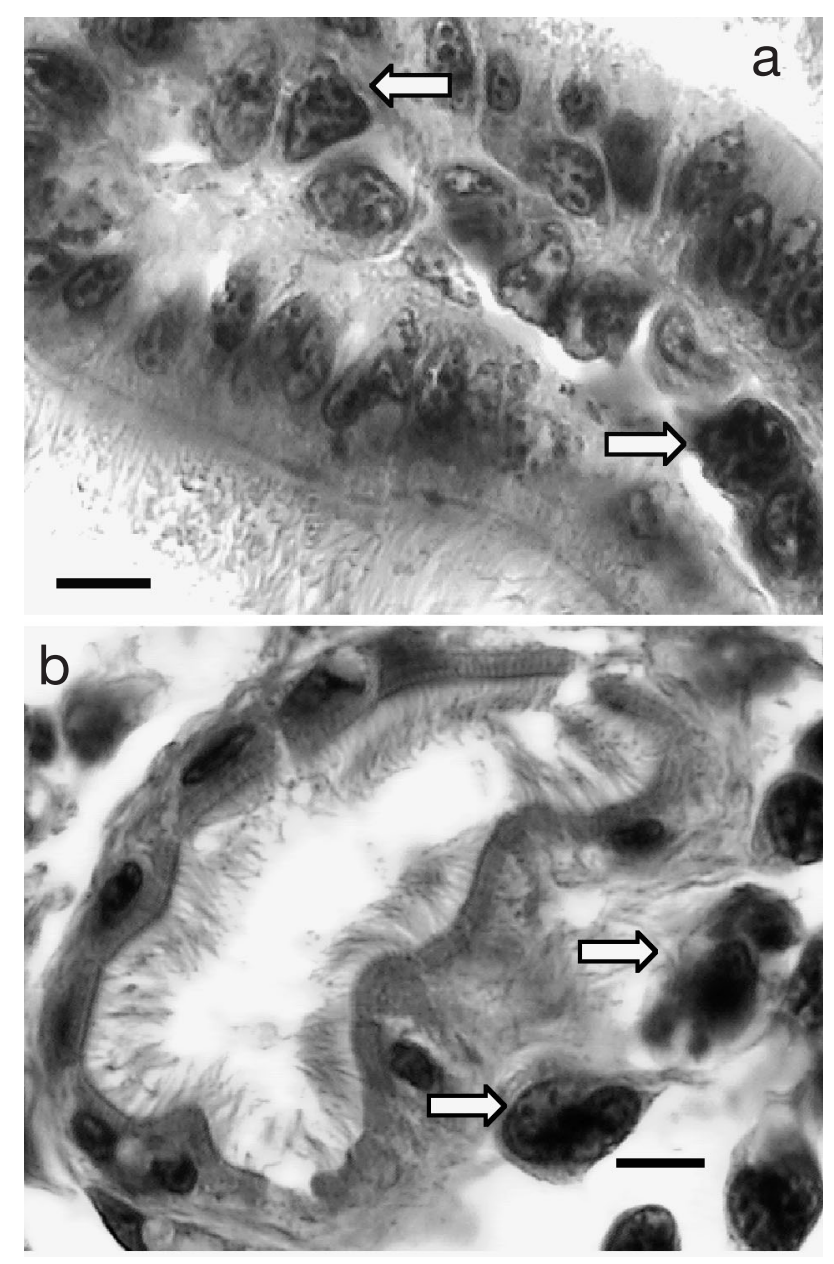

Fig. 2. Macoma balthica. Histological sections with neoplasia showing (a) stage II of the disease, changes confined to gills (arrows), and (b) stage IV, digestive gland. Arrows show neoplastic cells. Scale bars $=5 \mu \mathrm{m}, \mathrm{H} \& \mathrm{E}$ staining

peak was $42.1 \% \pm 4.8$ for peak $\mathrm{B}^{\prime}$, and $47.5 \% \pm 4.7$ for peak C' (Fig. 4d).

In affected clams, the ratio of mean fluorescence values between peaks $B^{\prime}$ and $C^{\prime}$ was higher than in normal clams (2.36). The relation between both peaks was: peak $\mathrm{C}^{\prime}=2.36$ peak $\mathrm{B}^{\prime}+1(\mathrm{~N}=15)$. The fluorescence ratio between peaks in normal clams was $0.49 \pm$ 0.01 versus $0.42 \pm 0.01$ in affected clams (Fig. 5a). The prevalence of peaks $\left(\mathrm{B}^{\prime} / \mathrm{B}^{\prime}+\mathrm{C}^{\prime}\right.$ ratio) was $0.68 \pm 0.04$ for affected animals versus $0.93 \pm 0.04$ for normal individuals (Fig. 5b). Both ratios (normal versus affected clams) were significantly different ( $p<0.0001)$.

\section{Chromosome analysis}

In clams defined as normal using histology, chromosomes were metacentric (11 pairs), submetacentric 

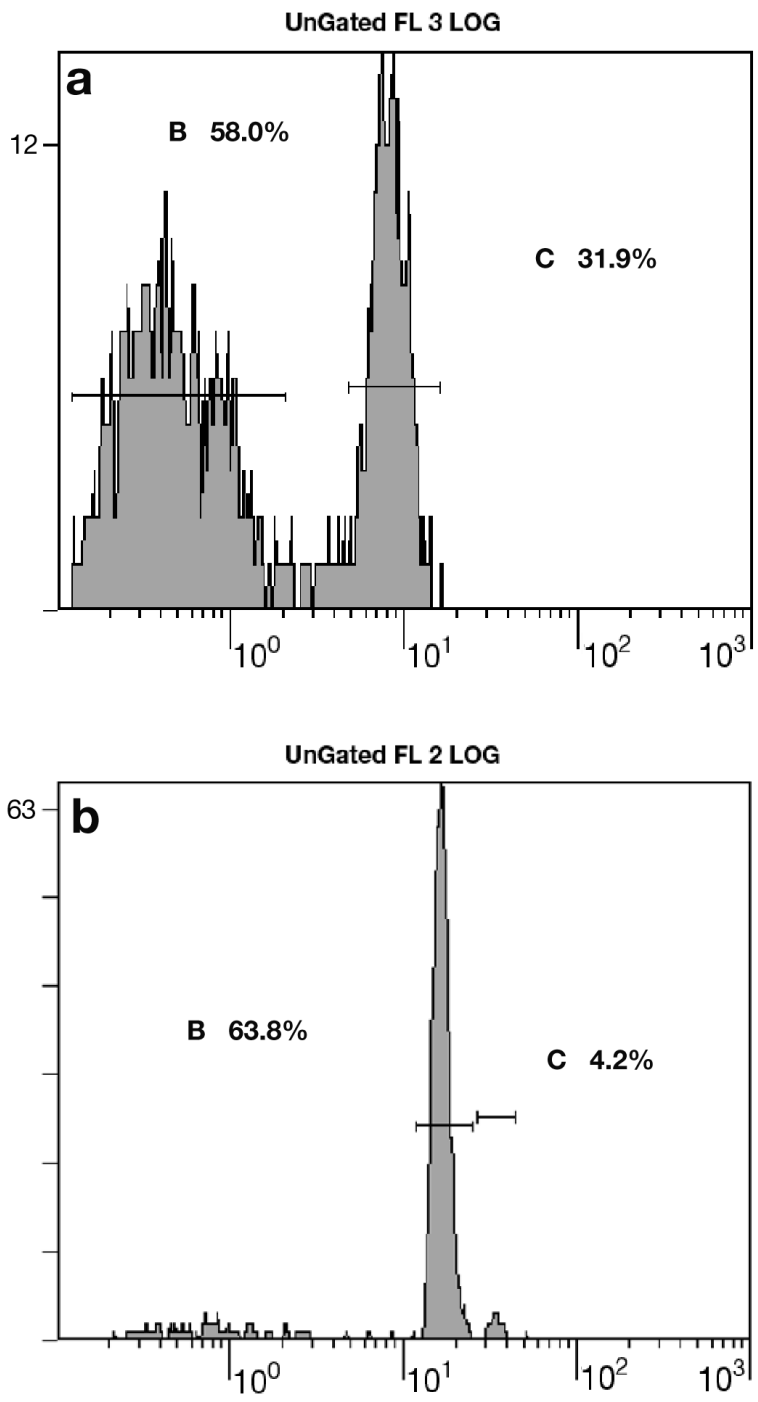

Fig. 3. Macoma balthica. Fluorescence (FL 3 LOG) histogram of normal clams. (a) Poor separation of the cell cycle peaks (cell permeabilisation using a buffer containing Triton X), (b) good definition of peaks under conditions in which osmotic shock was used. Histograms show the cell fluorescence (red fluorescence: FL 3, $x$-axis; number of cells, $y$-axis)

( 2 pairs) and subtelocentric (6 pairs) without evidence of telocentric chromosomes and micro-chromosomes (Fig. 6a). In affected clams, the chromosomal number ranged from 59 to 105, with a median of 90 in individuals with neoplasia (Fig. 6b). This range of chromosome number corresponds to 1.55-2.76 (median 2.37) of diploid. In all abnormal metaphases, telocentric and micro-chromosomes were present and there was a general increase in the amount of all genetic material present. In gill cells from affected clams, mitotic activity was high and up to 500 mitoses occurred (data not shown).
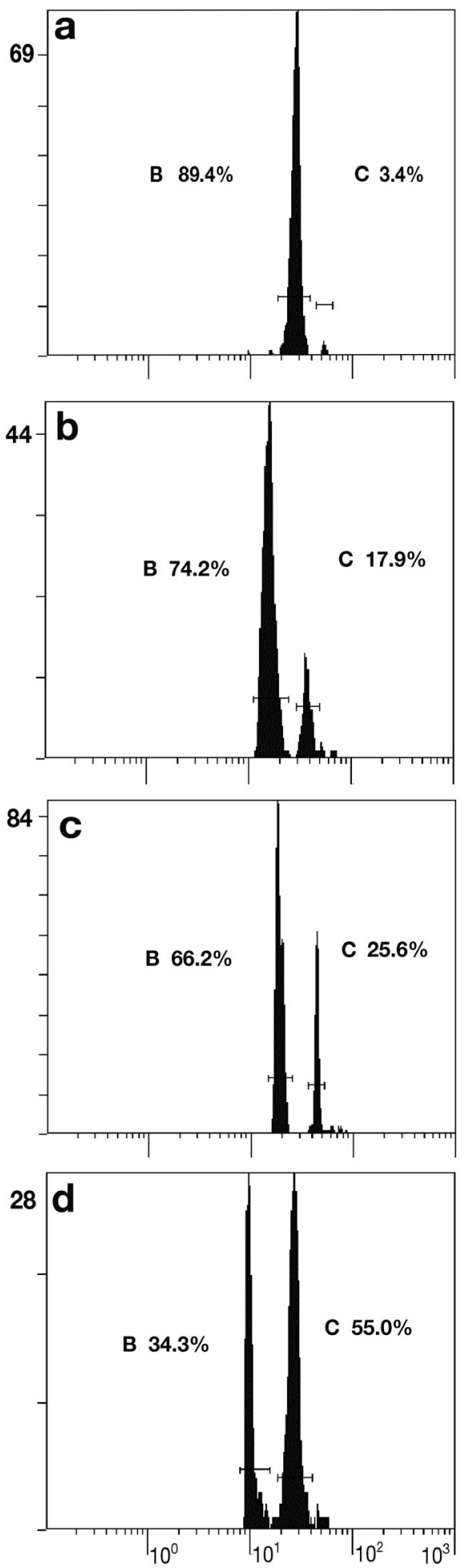

Fig. 4. Macoma balthica. Cytometric profiles of (a) normal and (b to d) affected individuals by neoplasia. (b) The first stage of neoplasia, characterised by high percentage of cells in the first peak and small population of abnormal cells (clam no. 1); (c) the second stage of neoplasia (clam no. 6); (d) stage 3 of neoplasia (clam no. 10). Histograms show the cell fluorescence (red fluorescence: FL3, $x$-axis) and number of cells (y-axis) 
Table 1. Macoma balthica. Flow cytometry analysis of normal clams ( $\mathrm{N}=15)$

\begin{tabular}{|lccccc|}
\hline $\begin{array}{l}\text { Clam } \\
\text { no. }\end{array}$ & $\begin{array}{c}\text { Mean } \\
\text { fluorescence } \\
\text { value of the } \\
\text { first peak }\end{array}$ & $\begin{array}{c}\text { \% of events } \\
\text { in the } \\
\text { first peak }\end{array}$ & $\begin{array}{c}\text { Mean } \\
\text { fluorescence } \\
\text { value of the } \\
\text { second peak }\end{array}$ & $\begin{array}{c}\text { \% of events } \\
\text { in the } \\
\text { second peak }\end{array}$ & $\begin{array}{c}\text { Ratio of } \\
\text { second and } \\
\text { first peak }\end{array}$ \\
\hline 1 & 18.15 & 88.72 & 39.5 & 6.24 & 2.17 \\
2 & 17.9 & 82.87 & 38.3 & 7.55 & 2.13 \\
3 & 13.75 & 85.19 & 28.95 & 6.76 & 2.1 \\
4 & 16.8 & 90.29 & 34.5 & 5.01 & 2.05 \\
5 & 19.5 & 83.83 & 41.45 & 6.38 & 2.12 \\
6 & 19.95 & 86.79 & 42.1 & 5.45 & 2.11 \\
7 & 18.7 & 83.17 & 38.95 & 7.28 & 2.08 \\
8 & 19.65 & 88.01 & 41.2 & 4.44 & 2.09 \\
9 & 20.15 & 86.08 & 42.5 & 6.31 & 2.1 \\
10 & 17.25 & 87.08 & 35.55 & 5.16 & 2.06 \\
11 & 17.6 & 85.07 & 35.55 & 6.85 & 2.01 \\
12 & 20.55 & 86.65 & 34.95 & 5.84 & 1.7 \\
13 & 19.0 & 86.52 & 37.35 & 6.16 & 1.96 \\
14 & 18.4 & 85.8 & 35.6 & 6.27 & 1.93 \\
15 & 20.55 & 82.59 & 41.9 & 7.27 & 2.03 \\
Mean & 18.53 & 85.91 & 37.89 & 6.2 & 2.04 \\
SD & 1.77 & 2.2 & 3.77 & 0.89 & 0.14 \\
& & & & & \\
\hline
\end{tabular}

\section{Technique comparison}

Proportions of normal and affected Macoma balthica detected by flow cytometry were similar to those determined by chromosome analysis and histology (Table 3). Abnormal cells were detected using flow cytometry and cytogenetic analysis in all 15 clams defined by histology as affected. On the basis of cell percentage in both $\mathrm{B}^{\prime}$ and $\mathrm{C}^{\prime}$ peaks, 3 different stages (1,2 and 3 ) of neoplasia were defined using flow cytometry (Table 2). Stage 1 as defined by flow cytometry corresponded to stages I and II defined by histology (Table 3). Stages 2 and 3 using flow cytometry analysis corresponded to stages III and IV observed by histology, respectively (Table 3 ). The 3 stages of neoplasia identified by flow cytometry (1, 2 and 3) appeared significantly dif-
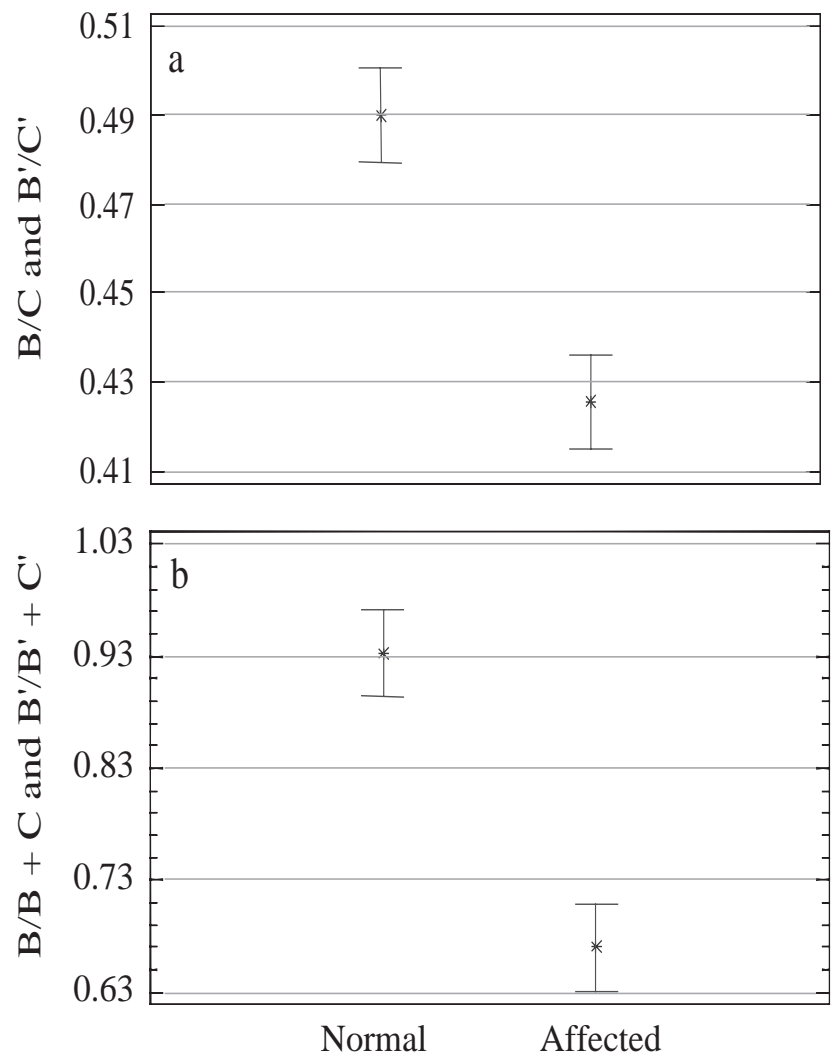

Fig. 5. Macoma balthica. Analysis of the peaks (mean and interval at 95\% LSD) between normal and affected clams. (a) Mean fluorescence value of the ratio peaks B/C and B'/C', data normalised using Arc Sin $\sqrt{ }$. (b) Mean prevalence of ratio of the peaks $\mathrm{B} / \mathrm{B}+\mathrm{C}$ and $\mathrm{B}^{\prime} / \mathrm{B}^{\prime}+\mathrm{C}^{\prime},(\mathrm{p}<0.0001)$
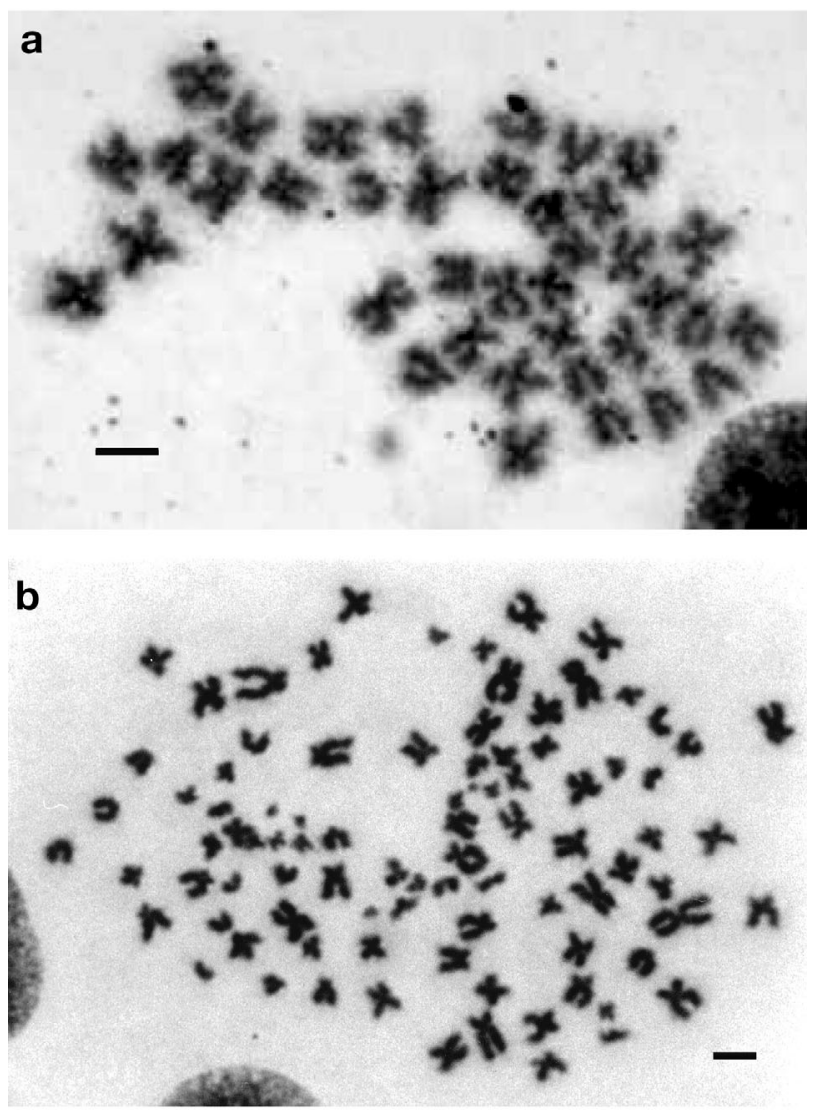

Fig. 6. Macoma balthica. Giemsa-stained metaphases in gills of (a) normal $M$. balthica with $2 \mathrm{n}=38$ and (b) affected $M$. balthica with 90 chromosomes. Scale bars $=5 \mu \mathrm{m}$ 


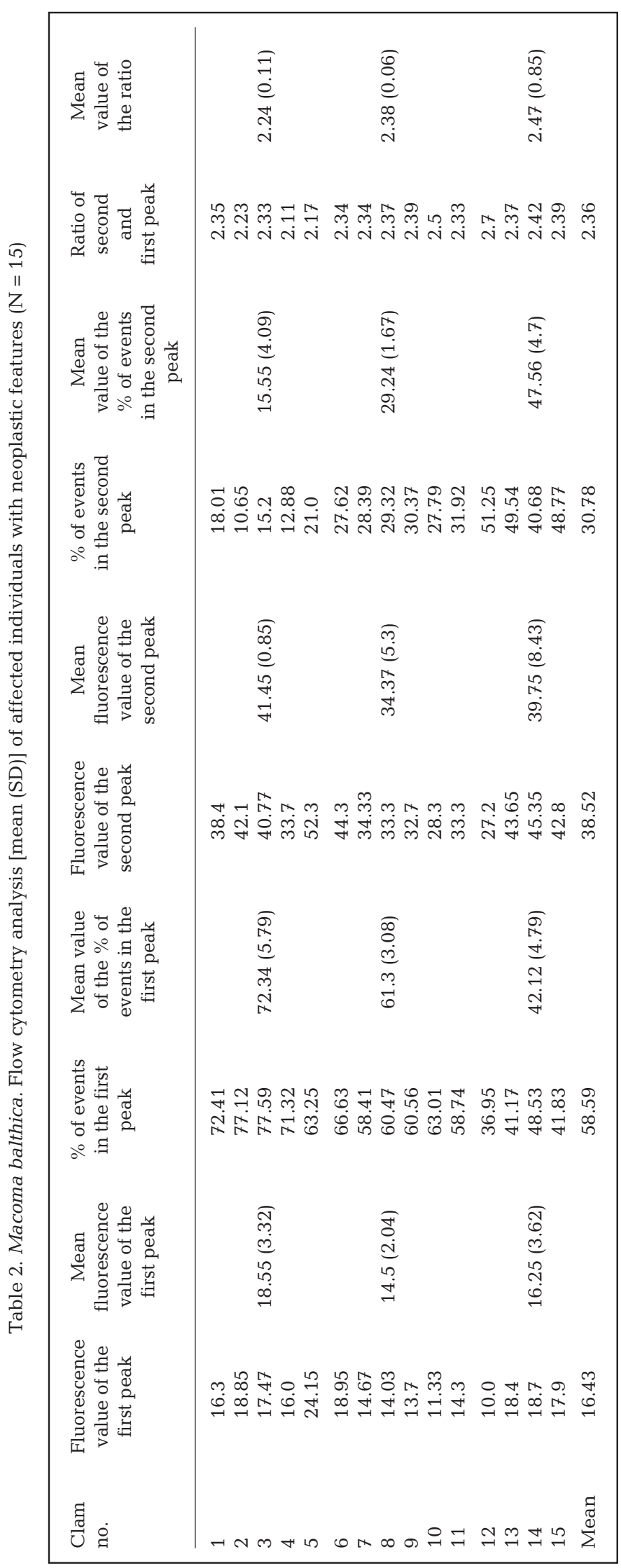

ferent (Fig. 7, p < 0.0001). The presence of 5 clams in stage 1 of neoplasia defined by flow cytometry was confirmed using chromosome analysis. In 1 affected clam (no. 2), the number of mitoses was too low for successful diagnosis using the cytogenetic method. The second (as defined by flow cytometry) and the third (as defined by histology) stage of neoplasia was confirmed in 6 clams. Chromosome analysis showed a higher presence of abnormal mitosis only in clam no. 11 (up to 345 mitoses, data not shown). For the same clam, histology showed a higher level of neoplasia in gonadal tissue, but a lower level in other organs. In clam no. 8, the prevalence of neoplasia was high in gills, but low in gonads and other organs. Stage 3 of neoplasia (defined by flow cytometry) and IV (defined by histology) was observed in 4 clams. The occurrence of neoplastic cells was high in all organs.

\section{DISCUSSION}

Histology is a suitable technique for the identification of neoplastic cells in bivalves, including those in early stages (Christensen et al. 1974, Elston et al. 1992, Pekkarinen 1993). In the present study, histology was used as the reference technique. Thirty animals were selected to compare the capability of flow cytometry, chromosome analysis and histology to diagnose neoplasia in clams, Macoma balthica, from the Gulf of Gdansk (Poland). Affected clams displayed the same kind of cell abnormality as previously described (Christensen et al. 1974, Elston et al. 1992, Pekkarinen 1993, Reno 1994): hypertrophied cells with enlarged nuclei and multiple nucleoli, and invasion of neoplastic cells to different organs in the later stages. Four histological stages were classified in affected $M$. balthica according to Christensen et al. (1974) and Pekkarinen (1993). In both studies, a gill-originating carcinoma was described. In the first stages of neoplasia, abnormal cells were also present in the connective tissue of gills. This may correspond to a haemocytic origin of the neoplasia as previously described in other bivalve species (Elston et al. 1992, Bower et al. 1994, Rodriguez et al. 1997).

In the present study, flow cytometry was used to determine DNA content of normal and affected Macoma balthica gill cells. Flow cytometry has already been used to study neoplasia in bivalves (Elston et al. 1990, Moore et al. 1991, Reno et al. 1994). In previous studies, authors analysed haemocytes collected from Mytilus sp. and from Mya arenaria. A simple and rapid protocol of cell 
Table 3. Macoma balthica. Summary of results obtained using flow cytometry, chromosome analysis and histology examination. (+) lowest number of abnormal cells; (++) marked presence of abnormal cells; (+++) highest number of abnormal cells. I, II, III, IV = the respective stages of neoplasia as defined by histology

\begin{tabular}{|c|c|c|c|c|c|c|}
\hline \multirow{2}{*}{$\begin{array}{l}\text { Clam } \\
\text { no. }\end{array}$} & \multirow{2}{*}{$\begin{array}{c}\text { Flow } \\
\text { cytometry }\end{array}$} & \multirow{2}{*}{$\begin{array}{c}\text { Cyto } \\
\text { genetics }\end{array}$} & \multirow[b]{2}{*}{ Gills } & \multicolumn{2}{|c|}{ Histology } & \multirow[b]{2}{*}{$\begin{array}{c}\text { Stage of } \\
\text { neoplasia }\end{array}$} \\
\hline & & & & Gonads & Other & \\
\hline 1 & - & - & - & - & - & 0 \\
\hline 2 & - & - & - & - & - & 0 \\
\hline 3 & - & - & - & - & - & 0 \\
\hline 4 & - & - & - & - & - & 0 \\
\hline 5 & - & - & - & - & - & 0 \\
\hline 6 & - & - & - & - & - & 0 \\
\hline 7 & - & - & - & - & - & 0 \\
\hline 8 & - & - & - & - & - & 0 \\
\hline 9 & - & - & - & - & - & 0 \\
\hline 10 & - & - & - & - & - & 0 \\
\hline 11 & - & - & - & - & - & 0 \\
\hline 12 & - & - & - & - & - & 0 \\
\hline 13 & - & - & - & - & - & 0 \\
\hline 14 & - & - & - & - & - & 0 \\
\hline 15 & - & - & - & - & - & 0 \\
\hline 1 & + & + & + & + & - & II \\
\hline 2 & + & - & + & + & - & I \\
\hline 3 & + & + & + & - & - & I \\
\hline 4 & + & + & + & + & + & II \\
\hline 5 & + & + & + & + & + & II \\
\hline 6 & ++ & ++ & ++ & ++ & ++ & III \\
\hline 7 & ++ & ++ & ++ & ++ & ++ & III \\
\hline 8 & ++ & ++ & ++ & + & + & III \\
\hline 9 & ++ & ++ & ++ & ++ & ++ & III \\
\hline 10 & ++ & +++ & ++ & ++ & ++ & III \\
\hline 11 & ++ & +++ & ++ & +++ & + & III \\
\hline 12 & +++ & +++ & +++ & +++ & ++ & IV \\
\hline 13 & +++ & ++ & ++ & +++ & ++ & IV \\
\hline 14 & +++ & ++ & ++ & +++ & ++ & IV \\
\hline 15 & +++ & +++ & +++ & +++ & ++ & IV \\
\hline
\end{tabular}

permeabilisation was developed. Permeabilisation using Triton-X 100 resulted in high percentages of non-labelled events. All events were counted and no gate defined. Thus, preliminary work was carried out using an osmotic shock. Water at different salinities was used. Total cell permeabilisation was detected solely in distilled water. Clams inhabit estuarine waters with low salinities, and gill cells may support great variations of salinity.

The cytometric pattern of normal cells consisted of 2 peaks (B and C). The major peak B is interpreted as the G0/G1 phase of the cell cycle and describes resting cells. Peak $\mathrm{C}$ could be identified as normal cells in the G2/M phase (dividing cells). The mean fluorescence value of peak $\mathrm{C}$ is double the value of peak B. Low prevalence of dividing cells corresponds to the normal status of bivalve gill cells. However, no internal standard was used to confirm this hypothesis. In previous studies by Elston et al. (1990) and Reno et al. (1994), internal standards were used in order to determine DNA content in Mytilus sp. and Mya arenaria cells, respectively. Mussel sperm was used as a standard by Elston et al. (1990), while Reno et al. (1994) used human lymphocytes and rainbow trout erythrocytes as a standard. However the use of vertebrate DNAs as standards may not be suitable. Propidium iodide penetration in vertebrate and bivalve cells may be different. No standard is available from Macoma balthica. In order to use sperm cells as a standard we must know the status of ploidy of the reference population. Individuals used in this study were characterised by high prevalence of neoplasia. Thiriot-Quiévreux \& Wolowicz $(1996,2001)$ established that more than $30 \%$ of clams from the Gulf of Gdansk are affected by neoplasia, and that gonads may also be affected.

The cytometric pattern of neoplastic clams (defined using histology) consisted of 2 peaks, $\mathrm{B}^{\prime}$ and $\mathrm{C}^{\prime}$. Peak $\mathrm{B}^{\prime}$ may be interpreted as a normal, diploid cell population in the G0/G1 phase based on mean fluorescence value, and may correspond to peak B detected in normal clams. The second peak $\mathrm{C}^{\prime}$ may consist of dividing normal cells in the G2/M phase or of neoplastic cells in the G0/G1 phase (population of aneuploid cells). However, cytogenetic examination suggested that the second hypothesis is more probable. Moreover, the relation between both peaks indicates that cells in the second peak contain more than the double the DNA present in cells from the first peak.
Fig. 7. Macoma balthica. Prevalence ratio (mean and interval at $95 \% \mathrm{LSD})$ of the peaks $\mathrm{B}^{\prime} /\left(\mathrm{B}^{\prime}+\mathrm{C}^{\prime}\right)$ in clams. Three stages of neoplasia are identified (ANOVA, data normalised using Arc Sin $\sqrt{ }, p<0.0001)$ 
Three stages of neoplasia were clearly distinguished on the basis of the ratio of $C^{\prime}$ peak prevalence. The percentage of events counted in the $C^{\prime}$ peak and the ratio between both peaks ( $\mathrm{B}^{\prime}$ and $\mathrm{C}^{\prime}$ ) is higher than in normal clams. Moreover, the mean value of fluorescence for $\mathrm{C}^{\prime}$ peak corresponds to pentaploid cells (diploid value $\times 2.36$ ) and occurs in 3 stages of neoplasia. The range of chromosome numbers scored in abnormal mitosis (diploid value $\times 2.37$ ) is similar to the mean value carried out using flow cytometry. For diploid cells of Macoma balthica, the diploid number of chromosomes is 38. Abnormal metaphases mainly consist of around 90 chromosomes, as previously reported by Thiriot-Quiévreux \& Wolowicz $(1996,2001)$.

In the present study, results obtained using flow cytometry, chromosome analysis and histology examination were compared. The mitotic index of neoplastic cells in clams scored in chromosome preparations coincided well with the proportion of abnormal cells in the G0/G1 phase obtained by flow cytometry. Although flow cytometry appears no more sensitive than histology and chromosome analysis, flow cytometry provides a rapid method for neoplasia detection and discrimination of aneuploid cells as well as for identification of the ploidy of the population. Osmotic shock is a simple technique to permeabilise cells. The technique enables objective and easy detection of neoplasia and provides a rapid method for measuring the DNA content of thousands of cells per individual. As it was difficult to develop the standard of the value, 2 parameters were used: 1) the percentage of cells in both $\mathrm{B}^{\prime}$ and $\mathrm{C}^{\prime}$ peaks, and 2) the ratio between the fluorescence value of $\mathrm{B}^{\prime}$ and $\mathrm{C}^{\prime}$ peaks while describing abnormalities of the populations. Results demonstrated a good correlation to those obtained using the other 2 techniques. Thus, it appears that flow cytometry is a valid technique for the analysis of neoplasia prevalence in Macoma balthica populations from different geographical origins .

Acknowledgements. This study was supported by funds from the Marie Curie Host Fellowships (no. QLK5-CT-2001-60036) provided by the European Commission. P. Goulletquer is acknowledged for allowing the work at the IFREMER station in La Tremblade (Charente Maritime, France). We thank C. Thiriot-Quiévreux (CNRS, INSU, Villefranche sur Mer, France) for helpful comments on the manuscript, Dr. R.-M. Le Deuff and Dr. G. D. Stentiford (CEFAS, Weymouth laboratory, UK) for improving the English and R. Lasota (University of Gdansk, Gdynia, Poland) for collecting samples.

\section{LITERATURE CITED}

Bower SM, McGladdery SE, Price IM (1994) Synopsis of infectious diseases and parasites of commercially exploited shellfish. Annu Rev Fish Dis 4:1-199
Brousseau P, Pellerin J, Morin Y, Cyr D, Blakley B, Boermans H, Fournier M (2000) Flow cytometry as a tool to monitor the disturbance of phagocytosis in the clam Mya arenaria haemocytes following in vitro exposure to heavy metals. Toxicology 142:145-156

Christensen DJ, Farley CA, Kern FG (1974) Epizootic neoplasms in the clam Macoma balthica (L.) from Chesapeake Bay. J Natl Cancer Inst 52:1739-1749

Elston RA, Drum AS, Allen SK Jr (1990) Progressive development of circulating polyploid cells in Mytilus with hemic neoplasia. Dis Aquat Org 8:51-59

Elston RA, Moore JD, Brooks K (1992) Disseminated neoplasia of bivalve molluscs. Rev Aquat Sci 65:405-466

Farley CA, Banfield WG, Kasnic G Jr, Foster WS (1972) Oyster herpes-type virus. Science 178:759-760

Ford SE, Barber RD, Marks E (1997) Disseminated neoplasia in juvenile oyster Crassostrea virginica and its relationship to the reproductive cycle. Dis Aquat Org 28:73-77

Fournier M, Pellerin J, Clermont Y, Morin Y, Brousseau P. (2001) Effects of in vivo exposure of Mya arenaria to organic and inorganic mercury on phagocytic activity of hemocytes. Toxicology 161:201-211

Hummel H, Sokolowski A, Bogaards R, Wolowicz M (2000) Ecophysiological and genetic traits of the clam Macoma balthica in the Baltic: differences between populations in the Gulf of Gdansk due to acclimatization or genetic adaptation? Int Rev Hydrobiol 85:621-637

Krishnakumar PK, Casillas E, Snider RG, Kagley AN, Varanasi U (1999) Environmental contaminants and the prevalence of hemic neoplasia (leukemia) in the common mussel (Mytilus edulis complex) from Puget Sound, Washington, USA. J Invertebr Pathol 73:135-146

Landsberg JH (1996) Neoplasia and biotoxin in bivalves: is there a connection? J Shellfish Res 15:203-230

Mix MC (1983) Haemic neoplasms of bay mussels, Mytilus edulis, from Oregon: Occurrence, prevalence, seasonality and histopathological progression. J Fish Dis 6:239-248

Moore JD, Elston RA, Drum AS, Wilkinson MT (1991) Alternate pathogenesis of systemic neoplasia in the bivalve mollusc Mytilus. J Invertebr Pathol 58:231-243

Naes K, Knutzen J, Berglind L (1995) Occurrence of PAH in marine organisms and sediments from smelter discharge in Norway. Sci Total Environ 163:93-106

Pekkarinen M (1993) Neoplastic diseases in the Baltic Macoma balthica (Bivalvia) off the Finnish Coast. J Invertebr Pathol 61:138-146

Reno PW, House M, Illingworth A (1994) Flow cytometric and chromosome analysis of soft-shell clams, Mya arenaria, with disseminated neoplasia. J Invertebr Pathol 64: 163-172

Rodriguez H, Soto M, Arias C, Estevez J (1997) A case of disseminated haemic sarcoma in Cerastoderma (=Cardium) glaucum Poiret 1789 collected from Ria de Vigo (NW Spain). Bull Eur Assoc Fish Pathol 17:88-90

Roy D, Colerangle JB, Kamleshwar PS (1998) Is exposure to environmental or industrial endocrine disrupting estrogen-like chemicals able to cause genomic instability? Front Biosci 3:913-921

Sauve S, Brousseau P, Pellerin J, Morin Y, Senecal L, Goudreau P, Fournier M (2002) Phagocytic activity of marine and freshwater bivalves: in vitro exposure of haemocytes to metals (Ag, Cd, Hg and Zn). Aquat Toxicol 58:189-200

Snedecor GW, Cochran WG (1957) Statistical methods. Ed Iowa State University Press

Sokolowski A, Wolowicz M, Hummel H, Bogaards R (1999) Physiological responses of Macoma balthica (L.) to copper pollution in the Baltic. Oceanol Acta 22:431-439 
Szefer P, Szefer K, Glasby GP, Pempkowiak J, Kaliszan R (1996) Heavy metal pollution in surficial marine sediments from the Gulf of Gdansk and the Southern Baltic Sea off Poland. J Environ Sci Health 31A:2723-2754

Thiriot-Quiévreux C, Ayraud N (1982) Les caryotypes de quelques especes de bivalves et gasteropodes marins. Mar Biol 70:165-172

Thiriot-Quiévreux C, Wolowicz M (1996) Etude caryologique d'une neoplasie branchiale chez Macoma balthica (Mollusca, Bivalvia). C R Acad Sci Paris 319:887-892

Thiriot-Quiévreux C, Wolowicz M (2001) Chromosomal study of spatial variation of the prevalence of a gill neoplasia in Macoma balthica (L.) from the Gulf of Gdansk (Baltic Sea). Ophelia 54:75-81

Editorial responsibility: Albert Sparks, Seattle, Washington, USA van Beneden RJ, Gardner GR, Blake NJ, Blair DG (1993) Implication of the presence of transforming genes in gonadal tumours in 2 bivalve mollusc species. Cancer Res 53:2976-2979

Villalba A, Carballal MJ, Lopez C (2001) Disseminated neoplasia and large foci indicating heavy haemocytic infiltration in cockles Cerastoderma edule from Galicia (NW Spain). Dis Aquat Org 46:213-216

Wolowicz M (1994) Impact de l'activité humaine sur les variations interannuelles de la malacofaune benthique en baie de Puck (S. Baltique). Haliotis 23:43-50

Yevich PP, Barszcz CA (1977) Neoplasia in soft-shell clams (Mya arenaria), collected from oil-impacted sites. Ann NY Acad Sci 298:409-426

Submitted: September 3, 2003; Accepted: January 7, 2005

Proofs received from author(s): June 23, 2005 